\title{
Good Corporate Governance Dan Free Cash Flow Terhadap Manajemen Laba PT. Tubagus Jaya Mahakarya Cilegon
}

\author{
Ihwan Satria Lesmana \\ Universitas Bina Bangsa Banten \\ ihwansatrialesmana@gmail.com
}

\section{Lilian Oktaviani \\ Universitas Bina Bangsa Banten \\ lilianoktavv@gmail.com}

\author{
Abdul Bahits \\ Universitas Bina Bangsa Banten \\ ab.bina_bangsa@yahoo.com
}

\begin{abstract}
Abstrak Good Corporate Governance dapat meminimalisir adanya manajemen laba, Good Corporate Governance merupakan suatu konsep monitoring untuk meningkatkan kinerja perusahaan yang dikelola oleh manajemen dan untuk menjaga akuntanbilitas manajemen dalam melindungi kepentingan stakeholder, sehingga diharapkan dapat menyelaraskan berbagai kepentingan. Perusahaan dengan arus kas bebas yang tinggi akan memiliki kesempatan yang lebih besar untuk melakukan manajemen laba. Penelitian ini digunakan untuk mengetahui pengaruh Good Corporate Governance dan Free Cash Flow terhadap Manajemen Laba pada PT. Tubagus Jaya Mahakarya Kota Cilegon Periode 2016-2018. Jenis penelitian yang digunakan dalam penelitian ini, yaitu penelitian kuantitatif dengan metode asosiatif kausal (hubungan). Hasil uji hipotesis Penerapan Good Corporate Governance dan free cash flow secara simultan terhadap manajemen laba diperoleh $F_{\text {hitung }}>F_{\text {tabel }}(20,980>3,316)$ dengan nilai signifikasi kurang dari 0,05, sehingga dapat disimpulkan bahwa terdapat pengaruh dan signifikan penerapan Good Corporate Governance dan Free Cash Flow secara simultan terhadap manajemen laba pada perusahaan PT. Tubagus Jaya Mahakarya Kota Cilegon periode tahun 2016-2018.
\end{abstract}

\section{Kata Kunci Manajemen Laba, Good Corporate Governance, Free Cash Flow}

\section{PENDAHULUAN}

Laba dapat digunakan untuk mengukur tingkat keberhasilan kinerja manajemen dalam mengelola perusahaan. Juga merupakan indikator untuk mengukur kinerja operasional. Hal tersebut memicu timbulnya perilaku oppoturnistik (menguntungkan diri sendiri) manajemen untuk melakukan praktik manipulasi laba yang sering disebut dengan manajemen laba. Praktik manajemen laba telah mengikis kepercayaan investor dalam kualitas pelaporan keuangan dan menghambat kelancaran arus modal di pasar keuangan. Oleh karena itu, perlu mekanisme pengendalian untuk menyelaraskan perbedaan kepentingan antara manajemen perusahaan (agent) dengan pemilik perusahaan 
(principal), yaitu good corporate governance yang salah satu tujuannya adalah untuk mencegah tindakan manajemen laba yang berlebihan. Praktik manajemen laba tidak dapat dipisahkan dari adanya teori keagenan. Teori keagenan merupakan dasar yang digunakan untuk memahami corporate governance, di mana masing-masing individu termotivasi oleh kepentingan dirinya sendiri, sehingga dapat menimbulkan konflik antara prinsipal dan agen. Pihak prinsipal termotivasi mengadakan kontrak untuk mensejahterakan dirinya dengan profitabilitas yang selalu meningkat, sedangkan agen termotivasi untuk memaksimalkan pemenuhan kebutuhan ekonomi dan psikologinya. Komponen yang dapat digunakan untuk mengetahui pengaruh dari Good Corporate Governance adalah dewan komisaris independen, komite audit dan kepemilikan manajerial yang diharapkan dapat meningkatkan proses pengawasan terhadap manajemen, sehingga mencegah perilaku opportunistik manajemen dan tindakan manajemen laba yang berlebihan.

Free cash flow yang terdapat di dalam perusahaan dapat menjadi pertanda baik maupun buruknya kinerja manajemen, sebab hal tersebut dapat menyebabkan munculnya masalah keagenan yang lebih besar antara pihak manajemen dengan pihak penanam modal. Perusahaan dengan arus kas bebas yang tinggi cenderung melakukan praktik manajemen laba dengan meningkatkan laba yang dilaporkan.

PT. Tubagus Jaya Mahakarya merupakan perusahaan jasa yang bergerak di bidang transportasi terutama melayani jasa bongkar muat barang dari dan ke atas kapal di wilayah pelabuhan IKPP (Indah Kiat Pulp Paper), Pelabuhan Merak Mas, Pelabuhan Ciwandan dan Pelabuhan KBS (Krakatau Bandar Samudera). Sama seperti perusahaan pada umumnya, orientasi utama yang ditargetkan oleh PT. Tubagus Jaya Mahakarya adalah laba. Laba yang dihasilkan oleh PT. Tubagus Jaya Mahakarya sangat bervariasi setiap bulannya. Hal ini memicu terjadinya manajemen laba. Salah satu faktor penyebab manajemen laba yang terjadi adalah karena belum diterapkannya Good Corporate Governance di PT. Tubagus Jaya Mahakarya secara optimal, sehingga manajemen dapat mempengaruhi informasi laba di dalam laporan keuangan dengan menaikkan atau menurunkan laba sesuai dengan keinginannya. Hal ini sejalan dengan penelitan yang berjudul pengaruh good corporate governance terhadap manajemen laba pada perusahaan yang masuk dalam JII (Jakarta Islamic Index) Tahun 2012-2013 dengan kesimpulan bahwa proporsi dewan komisaris independen berpengaruh positif dan signifikan terhadap manajemen laba (Dewi S \& Khoiruddin, 2016). Faktor lain terjadinya manajemen laba di PT. Tubagus Jaya Mahakarya adalah arus kas bebas (Free Cash Flow) yang tidak stabil. Keterlambatan pembayaran dari pihak pengguna jasa dapat menyebabkan perusahaan tidak optimal dalam membayar biaya operasional dan hutang perusahaan, karena arus kas bebas yang dimiliki rendah. Namun terkadang, selama beberapa periode PT. Tubagus Jaya Mahakarya juga memiliki arus kas bebas yang cenderung tinggi. Hal ini dapat disinyalir terjadinya manajemen laba. Dengan kata lain, arus kas bebas dapat mempengaruhi terjadinya manajemen laba. Hal ini pula sesuai dengan penelitian dengan tema pengaruh arus kas bebas, capital adequacy ratio dan good corporate governance Pada manajemen laba pada perusahaan food and beverage di BEI 2012-2017 yang memiliki kesimpulan bahwa arus kas bebas berpengaruh pada manajemen laba. Akan tetapi, pengaruh yang diberikan arus kas bebas adalah negatif (Yogi \& Damayanthi, 2016).

Berdasarkan observasi yang peneliti lakukan, pembayaran tagihan yang paling telat terjadi pada tahun 2018. Salah satu pengguna jasa PT. Tubagus Jaya Mahakarya mengalami kebangkrutan, sehingga meninggalkan jejak piutang sebesar Rp. 
1.113.736.070. Kebijakan yang diberikan oleh PT. Tubagus Jaya Mahakarya kepada perusahaan tersebut adalah memberikan sistem pembayaran secara kredit dengan jangka waktu yang telah ditetapkan pada setiap bulannya.

\section{LANDASAN TEORI}

\section{Good Corporate Governance}

Good corporate governance atau tata kelola perusahaan yang baik dapat didefinisikan sebagai sistem yang mengatur dan mengendalikan perusahaan untuk menciptakan nilai tambah bagi setiap stakeholders (I Guna \& Herawati, 2010). Ada dua hal yang ditekankan dalam mekanisme ini, pertama, pentingnya hak pemegang saham atau investor untuk memperoleh informasi dengan benar (akurat) dan tepat pada waktunya dan kedua, kewajiban perusahaan untuk melakukan pengungkapan secara akurat, tepat waktu dan transparan terhadap semua informasi kinerja perusahaan, kepemilikan dan stakeholder. Good Corporate Governance diartikan sebagai sistem yang mengatur dan mengendalikan perusahaan agar perusahaan itu menciptakan nilai tambah untuk semua stakeholdernya. Untuk itu, ada dua hal yang ditekankan dalam konsep ini, yaitu hak pemegang saham yang harus dipenuhi perusahaan dan kewajiban yang harus dilakukan perusahaan. Pemegang saham mempunyai hak untuk memperoleh semua informasi secara akurat dan tepat waktu. Corporate governance merupakan salah satu konsep yang dapat dipergunakan dalam meningkatkan efisiensi ekonomis, yang meliputi serangkaian hubungan antara manajemen perusahan lainnya. Corporate governance juga memberikan suatu struktur yang memfasilitasi penentuan sasaran-sasaran dari suatu perusahaan, dan sebagai sarana untuk menentuan teknik monitoring kinerja.

\section{Free Cash Flow}

Free cash flow (arus kas bebas) adalah arus kas yang benar-benar tersedia untuk dibayarkan kepada investor (pemegang saham dan pemilik utang) setelah perusahaan melakukan investasi dalam aset tetap, produk baru, dan modal kerja untuk mempertahankan operasi yang sedang berjalan (Bringham \& Houston, 2010). Semakin besar free cash flow yang tersedia dalam suatu perusahaan, maka akan semakin sehat perusahaan tersebut karena memiliki kas yang tersedia untuk pertumbuhan, pembayaran hutang, dan dividen. Sedangkan pendapat lain bahwa arus kas bebas (free cash flow) adalah jumlah yang tersedia dari operasi setelah investasi pada modal kerja operasional bersih dan aktiva tetap (Keown, 2011). Uang tunai yang tersedia ini kemudian didistribusikan kepada pemilik perusahaan dan kreditor atau secara dapat dikatakan setelah perusahaan membayar semua beban operasinya dan melakukan investasi, maka sisa kas didistribusikan kepada pemegang saham dan kreditor. Pendapat lainnya adalah arus kas bebas (free cash flow) adalah arus kas yang tersisa setelah menyediakan komitmen yang diperlukan untuk mempertahankan operasi pada tingkat sekarang. Komitmen ini meliputi operasi perusahaan yang sedang berjalan, pembayaran bunga, pajak penghasilan, pengeluaran modal bersih, dan dividen (Subramanyam \& Wild, 2010).

\section{Manajemen Laba}

Manajemen laba adalah suatu tindakan yang mengatur laba sesuai dengan yang dikehendaki oleh pihak tertentu atau terutama oleh manajemen perusahaan, tindakan tersebut didasarkan oleh berbagai tujuan dan maksud-maksud yang terkandung di dalamnya (Fahmi, 2011). Sedangkan di dalam jurnal bahwa manajemen laba merupakan 
tindakan manajemen dalam proses penyusunan laporan keuangan untuk mempengaruhi tingkat laba yang ditampilkan (Darmawati, 2003). Isu-isu dalam manajemen laba adalah sangat mudah untuk menduga bahwa manajemen laba bertujuan untuk memenuhi harapan dari analisis keuangan atau manajemen (yang diwakili oleh peramalan laba oleh publik). Begitu juga manajemen laba adalah sebagai campur tangan manajemen dalam proses pelaporan keuangan eksternal dengan tujuan menguntungkan dirinya sendiri (manajer) (I Guna \& Herawati, 2010). Berdasarkan beberapa definisi tersebut dapat disimpulkan bahwa manajemen laba merupakan usaha pihak manajemen yang disengaja untuk memanipulasi laporan keuangan dalam batasan yang diperbolehkan oleh prinsip-prinsip akuntansi dengan tujuan untuk memberikan informasi yang menyesatkan para pengguna laporan keuangan demi keuntungan manajer.

\section{METODOLOGI PENELITIAN}

\section{Tempat dan Waktu Penelitian}

Dalam rangka mendapatkan data, penulis mengadakan penelitian di PT. Tubagus Jaya Mahakarya yang beralamat di Komp. Arga Baja Pura, Jl. Arga Kawi Blok A5 No. 1212A. Kecamatan Gerogol, Kelurahan Kotasari, Cilegon-Banten. Penelitian ini dilakukan pada bulan Mei 2019 sampai bulan Agustus 2019.

\section{Populasi dan Sampel}

Populasi yang menjadi objek penelitian ini adalah pada seluruh laporan keuangan PT. Tubagus Jaya Mahakarya, sedangkan sampel adalah sebagian dari jumlah dan karakteristik yang dimiliki oleh populasi tersebut. Penelitian ini menggunakan sampel yang ditentukan dengan menggunakan metode Purposive Sampling. Metode tersebut membatasi pemilihan sampel berdasarkan kriteria tertentu.

Adapun kriteria laporan keuangan yang dijadikan sampel dalam penelitian ini, adalah:

1. Laporan keuangan PT. Tubagus Jaya Mahakarya periode 2016-2018.

2. Laporan keuangan yang dipublikasikan bulanan.

3. Laporan keuangan yang mempunyai data yang dibutuhkan dalam penelitian ini.

Berdasarkan kriteria pengambilan sampel seperti yang telah disebutkan di atas, maka sampel yang digunakan, yaitu laporan keuangan PT. Tubagus Jaya Mahakarya setiap bulan selama 3 tahun, yaitu 2016-2018. Berdasarkan pernyataan di atas, maka banyaknya sampel dalam penelitian ini adalah 36 sampel, yang diperoleh dari banyaknya bulan, yakni 12 bulan dalam setahun dikali 3 tahun.

\section{Jenis dan Sumber Data}

Dalam penelitian ini, jenis data menurut sifatnya, yaitu data kuantitatif. Jenis data menurut waktu pengumpulannya, yaitu data time series.

Sumber data yang digunakan adalah data sekunder, di mana data diperoleh secara tidak langsung dan telah dikumpulkan oleh pihak perusahaan maupun pihak lain (sumber atau responden) yang memiliki kaitan erat dengan objek penelitian.

\section{Analisis Data}

Analisis data yang digunakan dalam penelitian ini, antara lain menggunakan :

1. Uji Parsial (Uji t)

Uji t dilakukan untuk melihat pengaruh dari masing-masing variabel independen secara parsial terhadap variabel dependen. Pengujian dilakukan dengan tingkat signifikansi atau kepercayaan $5 \%$ atau $(\alpha)=0,05$ dengan kriteria pengujian : 
Keterangan

$$
t=\frac{r \sqrt{n-2}}{1-r^{2}}
$$

$\mathrm{t}=$ Nilai uji $\mathrm{t}$

$\mathrm{r}=$ Koefisien Korelasi Pearson

$\mathrm{r}^{2}=$ Koefisien Determinasi

$\mathrm{n}=$ Jumlah Sample

Uji ini dapat dilakukan dengan membandingkan $t_{\text {hitung }}$ dengan $t_{\text {tabel }}$ atau dengan melihat kolom signifikansi pada masing-masing thitung.

a. Menentukan tingkat signifikansi, yaitu 5\% dan derajat kebebasan $(\mathrm{dk})=\mathrm{n}-\mathrm{k}$ untuk menentukan nilai tabel.

b. Hasil thitung dibandingkan dengan $t_{\text {tabel }}$ dengan kriteria :

Jika $t_{\text {hitung }}<t_{\text {tabel}}$, maka $\mathrm{H}_{0}$ diterima

Jika $t_{\text {hitung }}>t_{\text {tabel, }}$ maka $\mathrm{H}_{0}$ ditolak

2. Uji Simultan (Uji F)

Uji $F$ bertujuan untuk mengetahui apakah semua variabel independen yang digunakan dalam model regresi secara bersama-sama berpengaruh terhadap satu variabel independen. Pengujian hipotesis secara simultan untuk membandingkan variabel yaitu:

a. Jika $F_{\text {hitung }}>\mathrm{F}_{\text {tabel}}$, dan signifikansi $\mathrm{t}<0,05$, maka $\mathrm{H}_{0}$ ditolak dan $\mathrm{H}_{\mathrm{a}}$ diterima, artinya variabel independen $\left(\mathrm{X}_{1}\right.$ dan $\left.\mathrm{X}_{2}\right)$ bersama-sama mempunyai pengaruh yang signifikan terhadap variabel dependen (Y).

b. Jika $F_{\text {hitung }}<\mathrm{F}_{\text {tabel }}$ dan signifikansi $\mathrm{t}>0,05$, maka $\mathrm{H}_{0}$ diterima dan $\mathrm{H}_{\mathrm{a}}$ ditolak, artinya variabel independen $\left(\mathrm{X}_{1}\right.$ dan $\left.\mathrm{X}_{2}\right)$ bersama-sama tidak mempunyai pengaruh yang signifikan terhadap variabel dependen $(\mathrm{Y})$.

3. Uji Koefisien Determinasi $\left(R^{2}\right)$

Uji Koefisien determinasi digunakan untuk melihat besarnya kontribusi variabel bebas terhadap variabel terikat. Dengan kata lain, koefisien determinasi digunakan untuk mengukur besarnya pengaruh variabel-variabel bebas yang diteliti, yaitu Good Corporate Governance $\left(\mathrm{X}_{1}\right)$ dan Free Cash Flow $\left(\mathrm{X}_{2}\right)$ dengan Manajemen Laba (Y) sebagai variabel terikatnya.

Adapun rumus koefisien determinasi yang digunakan adalah sebagai berikut:

Keterangan:

$$
\mathrm{Kd}=\mathrm{R}^{2} \times 100 \%
$$

$\mathrm{Kd}=$ Koefisien determinasi

$\mathrm{R}^{2}=$ Koefisien korelasi

Kriteria untuk analisis koefisien determinasi adalah:

a. Jika $\mathrm{Kd}$ mendekati nol (0), berarti pengaruh variabel independen terhadap variabel dependen lemah.

b. Jika Kd mendekati satu (1), berarti pengaruh variabel independen terhadap variabel dependen kuat.

\section{Pengujian Hipetesis}


Hipotesis merupakan asumsi dasar yang dibuat secara bebas tetapi logis. Asumsi dasar merupakan jawaban sementara terhadap permasalahan penelitian (Arikunto, 2012). Terdapat tiga hipotesis dala penelitian ini, adalah sebagai berikut :

Hipotesis Pertama

$\mathrm{H}_{0}: \beta_{1}=0 \quad$ Tidak terdapat pengaruh antara variabel Good Corporate Governance terhadap Manajemen Laba pada PT. Tubagus Jaya Mahakarya Kota Cilegon Periode 2016-2018.

$\mathrm{H}_{\mathrm{a}}: \beta_{1} \neq 0 \quad$ Terdapat pengaruh antara variabel Good Corporate Governance terhadap Manajemen Laba pada PT. Tubagus Jaya Mahakarya Kota Cilegon

Hipotesis Kedua Periode 2016-2018.

$\mathrm{H}_{0}: \beta_{2}=0$ Tidak terdapat pengaruh antara variabel Free Cash Flow terhadap Manajemen Laba pada PT. Tubagus Jaya Mahakarya Kota Cilegon Periode 2016-2018.

$\mathrm{H}_{\mathrm{a}}: \beta_{2} \neq 0 \quad$ Terdapat pengaruh antara variabel Free Cash Flow terhadap Manajemen Laba pada PT. Tubagus Jaya Mahakarya Kota Cilegon Periode 2016-2018.

Hipotesis Ketiga

$\mathrm{H}_{0}: \beta=0 \quad$ Tidak terdapat pengaruh antara variabel Good Corporate Governance dan Free Cash Flow terhadap Manajemen Laba pada PT. Tubagus Jaya Mahakarya Kota Cilegon Periode 2016-2018.

$\mathrm{H}_{\mathrm{a}}: \beta \neq 0 \quad$ Terdapat pengaruh antara variabel Good Corporate Governance dan Free Cash Flow terhadap Manajemen Laba pada PT. Tubagus Jaya Mahakarya Kota Cilegon Periode 2016-2018.

\section{HASIL PENELITIAN}

Diketahui dari data-data yang dimiliki yang kemudian melalui tahap pengolahan data, maka dapat dijelaskan beberapa analisis, sebagai berikut :

\section{Uji Parsial (Uji t)}

Uji ini digunakan untuk mengetahui apakah variabel independen secara parsial atau sendiri-sendiri berpengaruh terhadap variabel dependen. Pengambilan keputusan berdasarkan $t_{\text {hitung }}$ masing-masing koefisien regresi dengan nilai $t_{\text {tabel }}$ sesuai dengan tingkat signifikan yang digunakan sebesar $5 \%$.

a. Uji Parsial (Uji t) untuk Penerapan Good corporate governance $\left(\mathrm{X}_{1}\right)$ terhadap Manajemen laba (Y)

Untuk menguji keberpengaruhan apakah hipotesis yang ditetapkan semula diterima atau ditolak, dengan cara membandingkan antara thitung dengan $t_{\text {tabel. }}$. Hasil yang diperoleh dari SPSS 25 memberikan thitung untuk variabel Good corporate governance $\left(\mathrm{X}_{1}\right)$ terhadap manajemen laba $(\mathrm{Y})$ pada tabel di bawah ini:

Tabel 1 : Uji Parsial (Uji t) variabel Good Corporate Governance Coefficients $^{\mathrm{a}}$

\begin{tabular}{|c|c|c|c|c|c|c|}
\hline & \multirow[t]{2}{*}{ Model } & \multicolumn{2}{|c|}{ Unstandardized Coefficients } & $\begin{array}{l}\text { Standardized } \\
\text { Coefficients }\end{array}$ & \multirow[t]{2}{*}{$\mathrm{T}$} & \multirow[t]{2}{*}{ Sig. } \\
\hline & & B & Std. Error & Beta & & \\
\hline \multirow{3}{*}{1} & (Constant) & 20.014 & 2.981 & & 6.715 & .000 \\
\hline & GCG_X1 & 1.592 & 4.274 & .049 & .372 & .712 \\
\hline & FCF_X2 & -1.179 & .207 & -.742 & -5.694 & .000 \\
\hline
\end{tabular}


a. Dependent Variable: MAN.LABA (Y)

Berdasarkan tabel 1, diperoleh $\mathrm{t}_{\text {hitung }}$ sebesar 0,372 dan $\mathrm{t}_{\text {tabel }}$ adalah derajat kebebasan $(\mathrm{dk})=\mathrm{n}-2(33-2=31)$, dan diperoleh $\mathrm{t}_{\text {tabel }}$ sebesar 2,040, maka diperoleh hasil $t_{\text {hitung }}<t_{\text {tabel }}(0,372<2,040)$ dengan tingkat signifikansi sebesar 0,712>0,050 $(5 \%)$, sehingga dapat disimpulkan tidak terdapat pengaruh Good corporate governance terhadap manajemen laba pada PT. Tubagus Jaya Mahakarya Kota Cilegon periode tahun 2016-2018.

b. Uji Parsial (Uji t) untuk Free Cash Flow $\left(\mathrm{X}_{2}\right)$ terhadap Manajemen laba (Y) Untuk menguji keberpengaruhan apakah hipotesis yang ditetapkan semula diterima atau ditolak, dengan cara membandingkan antara $t_{\text {hitung }}$ dengan $t_{\text {tabel }}$. Hasil yang diperoleh dari SPSS 25 memberikan $t_{\text {hitung }}$ untuk variabel Free Cash Flow $\left(\mathrm{X}_{2}\right)$ terhadap manajemen laba $(\mathrm{Y})$ pada tabel di bawah ini :

Tabel 2 : Uji Parsial (Uji t) variabel Free cash flow Coefficients $^{\text {a }}$

\begin{tabular}{|c|c|c|c|c|c|c|}
\hline & \multirow[t]{2}{*}{ Model } & \multicolumn{2}{|c|}{ Unstandardized Coefficients } & $\begin{array}{l}\text { Standardized } \\
\text { Coefficients }\end{array}$ & \multirow[t]{2}{*}{$\mathrm{T}$} & \multirow[t]{2}{*}{ Sig. } \\
\hline & & B & Std. Error & Beta & & \\
\hline \multirow{3}{*}{1} & (Constant) & 20.014 & 2.981 & & 6.715 & .000 \\
\hline & GCG_X1 & 1.592 & 4.274 & .049 & .372 & .712 \\
\hline & FCF_X2 & -1.179 & .207 & -.742 & -5.694 & .000 \\
\hline
\end{tabular}

a. Dependent Variable: MAN.LABA (Y)

Berdasarkan tabel 2, diperoleh $t_{\text {hitung }}$ sebesar $-5,694$ dan $t_{\text {tabel }}$ adalah derajat kebebasan $(\mathrm{dk})=\mathrm{n}-2(33-2=31)$, dan diperoleh $\mathrm{t}_{\text {tabel }}$ sebesar $-2,040$, maka diperoleh hasil $-t_{\text {hitung }}<-t_{\text {tabel }}(-5,694<-2,040)$ dengan tingkat signifikansi sebesar $0,000<0,050(5 \%)$, sehingga dapat disimpulkan terdapat pengaruh dan signifikan Free Cash Flow terhadap manajemen laba pada Perusahaan PT. Tubagus Jaya Mahakarya Kota Cilegon periode tahun 2016-2018.

\section{Uji Simultan (Uji F)}

Uji ini digunakan untuk mengetahui apakah variabel independen secara simultan atau bersama-sama berpengaruh terhadap variabel dependen. Pengambilan keputusan berdasarkan $F_{\text {hitung }}$ masing-masing koefisien regresi dengan nilai $t_{\text {tabel }}$ sesuai dengan tingkat signifikan yang digunakan sebesar $5 \%$.

Dalam uji F untuk membuktikan apakah variable Good corporate governance $\left(\mathrm{X}_{1}\right)$, dan Free Cash Flow $\left(\mathrm{X}_{2}\right)$ secara simultan mempunyai pengaruh terhadap manajemen laba (Y), maka dilakukan uji F, sebagai berikut :

\section{Tabel 3 : Uji Simultan (Uji F)}

ANOVA ${ }^{a}$

\begin{tabular}{|r|l|r|r|r|r|r|}
\hline \multicolumn{2}{|c|}{ Model } & Sum of Squares & Df & Mean Square & F & \multicolumn{1}{c|}{ Sig. } \\
\hline \multirow{3}{*}{1} & Regression & 163.831 & 2 & 81.916 & 20.980 & $.000^{\mathrm{b}}$ \\
\cline { 2 - 8 } & Residual & 117.134 & 30 & 3.904 & & \\
\cline { 2 - 8 } & Total & 280.966 & 32 & & & \\
\hline
\end{tabular}

a. Dependent Variable: MAN. LABA (Y)

b. Predictors: (Constant), FCF (X2), GCG (X1) 
Berdasarkan tabel 3, diperoleh $\mathrm{F}_{\text {hitung }}=20,980$, sedangkan nilai $\mathrm{F}_{\text {tabel }}(\mathrm{dk}=\mathrm{n}-\mathrm{k}-1=33$ $2-1=30)$ sebesar 3,316 dengan tingkat signifikansi sebesar 0,000 $<0,05(5 \%)$, sehingga $\mathrm{F}_{\text {hitung }}>\mathrm{F}_{\text {tabel }}(20,980>3,316)$. Dengan demikian, secara simultan terdapat pengaruh dan signifikan penerapan Good corporate governance dan Free Cash Flow terhadap manajemen laba pada Perusahaan PT. Tubagus Jaya Mahakarya Kota Cilegon periode tahun 2016-2018. Hal ini berarti variable-variabel tersebut dapat dijadikan sebagai pengukur manajemen laba.

\section{Uji Koefisien Determinasi $\left(R^{2}\right)$}

Koefisien determinasi menunjukkan berapa persen dari variasi (naik turunnya) variabel dependent dapat diterangkan atau dijelaskan oleh variasi variabel independen, koefisien determinasi Good corporate governance $\left(\mathrm{X}_{1}\right)$ dan Free Cash Flow $\left(\mathrm{X}_{2}\right)$ terhadap Manajemen laba (Y) adalah sebagai berikut :

\section{Tabel 4 : Uji Koefisien Determinasi $\left(R^{2}\right)$ Model Summary ${ }^{b}$}

\begin{tabular}{|l|r|r|r|c|}
\hline Model & $\mathrm{R}$ & $\mathrm{R}$ Square & \multicolumn{1}{c|}{$\begin{array}{c}\text { Adjusted R } \\
\text { Square }\end{array}$} & $\begin{array}{c}\text { Std. Error of the } \\
\text { Estimate }\end{array}$ \\
\hline 1 & $.764^{\mathrm{a}}$ & .583 & \multicolumn{1}{c}{.555} & 1.97598 \\
\hline
\end{tabular}

Berdasarkan tabel 4, diperoleh nilai koefisien determinasi $\left(\mathrm{R}^{2}\right) R$ Square sebesar 0,583. Hal ini dapat diartikan bahwa variabel Good corporate governance dan Free Cash Flow mempengaruhi sebesar 58,3\% terhadap manajemen laba dan sisanya sebesar $41,7 \%$ dipengaruhi oleh faktor lain yang tidak diteliti dalam penelitian ini.

\section{Pembahasan}

Pada hipotesis penelitian diduga penerapan Good corporate governance secara parsial berpengaruh terhadap manajemen laba pada Perusahaan PT. Tubagus Jaya Mahakarya Kota Cilegon periode tahun 2016-2018 hasil perhitungan didapat thitung sebesar 0,372 dan $\mathrm{t}_{\text {tabel }}$ adalah Derajat Kebebasan $(\mathrm{dk})=\mathrm{n}-2(33-2=31)$ maka diperoleh $\mathrm{t}_{\text {tabel }}$ sebesar 2,040 didapat hasil $t_{\text {hitung }}<t_{\text {tabel }}(0,372<2,040)$ dengan tingkat signifikansi sebesar 0,712> 0,050 (5\%) maka dapat disimpulkan tidak terdapat pengaruh penerapan Good corporate governance terhadap manajemen laba pada Perusahaan PT. Tubagus Jaya Mahakarya Kota Cilegon periode tahun 2016-2018.

Hasil penelitian ini juga konsisten dengan temuan-temuan sebelumnya antara lain menurut (Dewi S \& Khoiruddin, 2016) hasil penelitian menunjukkan bahwa variabel kepemilikan konstitusional dan ukuran dewan komisaris dan ukuran komite audit tidak berpengaruh pada manajemen laba. Good corporate governance (GCG) berperan penting sebagai monitoring terhadap seluruh aktivitas operasional perusahaan, sehingga penerapan GCG yang baik diharapkan akan mampu mengurangi perilaku manajemen laba yang bersifat oportunis.

Pada hipotesis penelitian diduga Free Cash Flow secara parsial berpengaruh terhadap manajemen laba pada Perusahaan PT. Tubagus Jaya Mahakarya Kota Cilegon periode tahun 2016-2018 didapat $-\mathrm{t}_{\text {hitung }}$ sebesar $-5,694$ dan $-\mathrm{t}_{\text {tabel }}$ adalah derajat kebebasan $(\mathrm{dk})=$ $\mathrm{n}-2(33-2=31)$ maka diperoleh $-\mathrm{t}_{\text {tabel }}$ sebesar $-2,040$ didapat hasil $\mathrm{t}_{\text {hitung }}<\mathrm{t}_{\text {tabel }}(-5,694<-$ $2,040)$ dengan tingkat signifikansi sebesar $0,000<0,050(5 \%)$ maka dapat disimpulkan terdapat pengaruh dan signifikan Free Cash Flow terhadap manajemen laba pada Perusahaan PT. Tubagus Jaya Mahakarya Kota Cilegon periode tahun 2016-2018. 
Penelitian ini sesuai dengan penelitian (Agustia, 2013) yang menyatakan hasil penelitiannya Free Cash Flow berpengaruh negatif signifikan terhadap manajemen laba. Hal ini mengindikasikan bahwa semakin besar presentase free cash flow dalam suatu perusahaan akan dapat menurunkan terjadinya tindakan manajemen laba.

\section{KESIMPULAN}

Berdasarkan hasil dan pembahasan, dapat diambil kesimpulan bahwa good corporate governance tidak berpengaruh terhadap manajemen laba, sedangkan free cash flow berpengaruh terhadap manajemen laba. Akan tetapi, secara simultan terdapat pengaruh dan signifikan penerapan good corporate governance dan free cash flow terhadap manajemen laba pada PT. Tubagus Jaya Mahakarya Kota Cilegon periode tahun 20162018 , diperoleh $F_{\text {hitung }}>F_{\text {tabel }}(20,980>3,316)$ dengan tingkat signifikansi sebesar 0,000 $<0,050(5 \%)$. Serta, nilai koefisien determinasi $\left(\mathrm{R}^{2}\right) R$ Square sebesar 0,583 . Hal ini dapat diartikan bahwa variabel penerapan good corporate governance dan free cash flow mempengaruhi sebesar 58,3\% terhadap manajemen laba dan sisanya sebesar $41,7 \%$ dipengaruhi oleh faktor lain yang tidak diteliti dalam penelitian ini.

\section{DAFTAR PUSTAKA}

Agustia, D. (2013). Pengaruh Free Cash Flow dan Kualitas Audit Terhadap Manajemen Laba. E Jurnal Akuntansi UNAIR, AKRUAL 4 (2) 105-118 e-issn : 2502-6380.

Arikunto, S. (2012). Prosedur penelitian suatu pendekatan praktik. Jakarta: Rineka Cipta. Bringham, E., \& Houston, J. (2010). Dasar-dasar Manajemen Keuangan. Jakarta: Salemba Empat.

Darmawati, D. (2003). Corporate Governance dan Manajemen Laba: Suatu Studi Empiris. Jurnal Bisnis dan Akuntansi, Vol. 5, No. 1.

Dewi S, E., \& Khoiruddin, M. (2016). Pengaruh Good Corporate Governance Terhadap Manajemen Laba Pada Perusahaan Yang Masuk Dalam JII (Jakarta Islamic Index) Tahun 2012-2013. Jurnal Manajemen UNS, ISSN : 2252-6552.

Fahmi, I. (2011). Analisis Laporan Keuangan. Bandung: Alfabeta.

I Guna, W., \& Herawati, A. (2010). Pengaruh Mekanisme Good Corporate Governance, Independensi Auditor, Kualitas Audit Dan Faktor Lainnya Terhadap Manajemen Laba. STIE Trisakti : Jurnal Bisnis dan Akuntansi, Vol. 12, No. 1.

Keown, A. J. (2011). Dasar-dasar Manajemen Keuangan. Jakarta: Salemba Empat.

Subramanyam, K., \& Wild, J. (2010). Analisis Laporan Keuangan. Jakarta: Salemba Empat.

Yogi, L., \& Damayanthi, I. (2016). Pengaruh Arus Kas Bebas, Capital Adequacy Ratio dan Good Corporate Governance Pada Manajemen Laba pada Perusahaan Food and Beverage di BEI 2012-2017. E-Jurnal Akuntansi Uneversitas Udayana, Vol.15.2 ISSN 2302-8556. 